University of Florida Levin College of Law

UF Law Scholarship Repository

UF Law Faculty Publications

Faculty Scholarship

2020

Rethinking Major League Baseball's Antitrust Exemption

Roger D. Blair

University of Florida, roger.blair@warrington.ufl.edu

Wenche Wang

University of Michigan

Follow this and additional works at: https://scholarship.law.ufl.edu/facultypub

Part of the Antitrust and Trade Regulation Commons

Recommended Citation

Roger D. Blair \& Wenche Wang, Rethinking Major League Baseball's Antitrust Exemption, $30 \mathrm{~J}$. of Legal Aspects of Sport (2020)

This Article is brought to you for free and open access by the Faculty Scholarship at UF Law Scholarship Repository. It has been accepted for inclusion in UF Law Faculty Publications by an authorized administrator of UF Law Scholarship Repository. For more information, please contact kaleita@law.ufl.edu. 


\title{
Rethinking Major League Baseball's Antitrust Exemption
}

\author{
Roger D. Blair and Wenche Wang*
}

\begin{abstract}
For nearly a century, Major League Baseball (MLB) has enjoyed antitrust immunity. No other sports league or organization is similarly exempt. Shielded by precedent from antitrust prosecution, MLB clubs are free to exploit both monopolistic and monopsonistic power. In this paper, we call for a repeal of MLB's antitrust exemption. In doing so, we examine some recent antitrust challenges to MLB conduct, the current interest of the Department of Justice and the Federal Trade Commission in labor market issues, the welfare consequences of the exemption, and a policy recommendation for legislative action.
\end{abstract}

Keywords: Major League Baseball, antitrust exemption, monopoly, monopsony

\section{Introduction}

In 1922, Justice Oliver Wendell Holmes blundered badly in Federal Baseball ${ }^{1}$ by granting antitrust immunity to Major League Baseball (MLB). The purported foundation for this immunity was misguided if not actually disingenuous. The United States Supreme Court has had several opportunities to correct this injustice, but has refused to do so. In fact, the Court confirmed its commitment to this anomalous ruling in those cases where certiorari was granted. ${ }^{2}$ The economic consequences of MLB's antitrust exemption are the largely unfettered exercise of monopoly and monopsony power by the league and its members. In the market for MLB players, the exemption has been legislated away by Congress in the Curt Flood Act, but MLB is protected by the non-statutory labor exemption since the players are unionized. To a large extent, MLB's exemption has become irrelevant in the market for broadcast rights due to the Sports Broadcasting Act. ${ }^{3}$

\footnotetext{
1 Federal Baseball Club of Baltimore v. National League of Professional Baseball Clubs, 259 U.S. 200 (1922).

2 Toolson v. New York Yankees, 346 U.S. 356 (1953); Flood v. Kuhn, 407 U.S. 258 (1972).

315 U.S.C. $\$ 1291$.

* Roger D. Blair, PhD, is a professor and chair of the Department of Economics and affiliate faculty of law at the University of Florida; email: rdblair@ufl.edu. Wenche Wang, PhD, is an assistant professor of sport management in the School of Kinesiology at the University of Michigan; email: wwenche@umich.edu. Although they cannot be blamed for what follows, the authors would like to thank Isabelle Mercier and Ryan Rodenberg for truly useful suggestions. They also thank their discussant, Todd Jewell, and participants at the 2018 WEAI conference in Vancouver, Canada.
} 
In all other areas, however, the exemption appears to have current vitality for no good reason. MLB's anachronistic antitrust exemption is unique. No other sports league or organization enjoys antitrust immunity. Even the NCAA is subject to antitrust scrutiny. ${ }^{4}$ In this paper, we review the history and development of MLB's antitrust exemption. We discuss the welfare consequences due to MLB's antitrust immunity. There is no principled foundation for MLB's special status and we argue that it should be withdrawn.

The organization of the rest of the paper is as follows. In Section 2 of this paper, we review the economic consequences of collusion. In Section 3, we set out the antitrust treatment of collusion in labor markets outside baseball. We also examine the current concerns of the Department of Justice (DOJ) and the Federal Trade Commission (FTC) regarding antitrust policy in labor markets. Section 4 focuses on the judicial foundation for MLB's antitrust exemption. We turn to the current vitality of MLB's antitrust exemption in Section 5. Section 6 explores judicial resistance to a repeal of the exemption. In Section 7, we offer an argument for repeal of MLB's antitrust exemption and close with some concluding remarks in Section 8.

\section{The Economic Rationale for Antitrust Policy}

The fundamental premise of the antitrust laws is that competitive market forces can be relied upon to guide resource allocation in the most efficient way. In the absence of market failure, which may be due to externalities, public goods, or asymmetric information, competitive markets maximize social welfare. Thus, our antitrust policy appropriately aims to protect and promote competition through statutory provisions, public and private enforcement, and judicial interpretation. When there is a monopoly (i.e., a single seller) the consequences for consumers are familiar, higher prices and reduced output. When it comes to monopsony, however, the consequences are a bit less familiar. In this case, there is only one buyer and its efforts to maximize profit result in perhaps an initially counterintuitive result: lower prices paid and reduced purchases, which lead to higher prices for consumers. ${ }^{5}$ What generates political support for a vigorous antitrust policy are the prices that affect the distribution of wealth. For economists, however, the concern is with the allocative inefficiency of the output restrictions rather than the effect on wealth distribution. Here, we explore the impact of monopoly and monopsony on both income distribution and allocative efficiency.

4 National Collegiate Athletic Association v. Board of Regents of the University of Oklahoma, 468 U.S. 85 (1984).

5 See Roger D. Blair \& Jeffrey L. Harrison, Antitrust Policy and Monopsony, 76 Cornell LaW Review 297 (1991), for analytical details. Also, see Roger D. Blair \& Christine Piette Durrance. The Economics of Monopsony in W. Dale Collins, ed. Issues in Competition Law and Policy (2008). 


\subsection{Monopoly and its Welfare Consequences}

Consider a case of monopolization. Profit-maximization will lead the firm to operate where marginal revenue equals marginal cost. The economic results are captured in Figure 1 in which D represents demand, MR is the associated marginal revenue, and $\mathrm{S}$ denotes supply, which is marginal cost. The competitive solution can be found at the intersection of supply and demand: price is $\mathrm{P}_{1}$ and the quantity is $\mathrm{Q}_{1}$. In this partial equilibrium setting, ${ }^{6}$ our measure of consumer welfare is consumer surplus and our measure of social welfare is the sum of consumer surplus and producer surplus. Consumer surplus is the difference between the consumer's willingness to pay and the price that he or she actually pays. In Figure 1, this is the area under the demand curve above (i.e., the triangular area ). Producer surplus is the difference between a producer's reservation price and the price actually received. In Figure 1, producer surplus is the area above the supply curve and below $\mathrm{P}_{1}$ (i.e., the triangular area $\mathrm{P}^{1} b c$ ). The sum of consumer surplus and producer surplus is a measure of social welfare. Given the demand and supply conditions in this market, social welfare is maximized at the competitive equilibrium of $\mathrm{P}_{1}$ and $Q_{1}$. No other price and output will generate a larger social welfare. In a nutshell, this is the economic rationale for a public policy that promotes and protects competition.

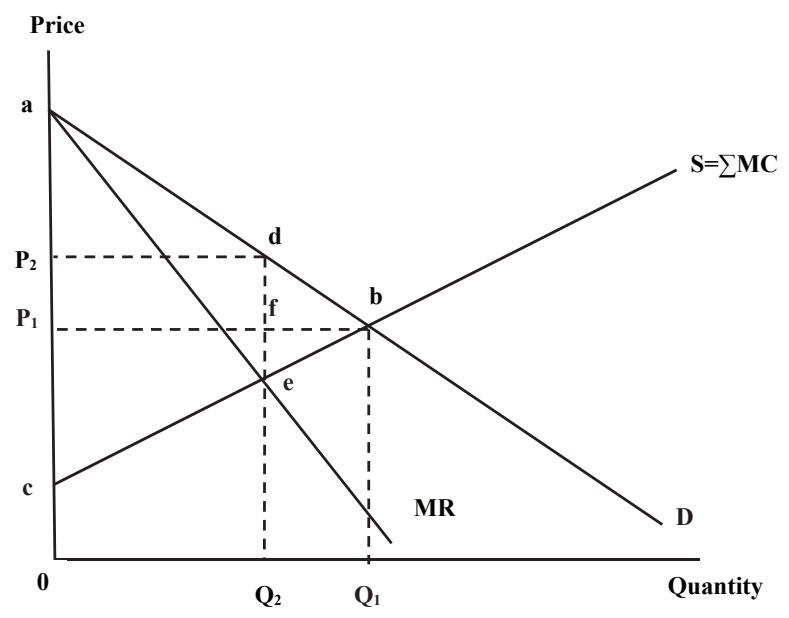

Figure 1

If this market is monopolized, the monopolist will maximize its profits by reducing output to $Q_{2}$ (where marginal revenue equals marginal cost) and raising price to $P_{2}$. Profit maximization by the monopolist reduces consumer surplus from area $a b P_{1}$ to area $a d P_{2}$. Some of the lost consumer surplus, area $P_{2} d f P_{1}$, is

\footnotetext{
${ }_{6}$ By partial equilibrium, we mean that the analysis is confined to this particular market. All other markets are ignored.
} 
converted into producer surplus (or profit) while the rest is simply lost. In terms of social welfare, the loss due to monopoly is equal to area $d b e$. This is the sum of the forgone consumer surplus and producer surplus from not producing at $Q_{1}$.

Thus, monopoly alters the distribution of the surplus by converting some consumer surplus into profit. Not surprisingly, consumers find this objectionable. But monopoly also reduces the total surplus because of the output restriction. In Figure 1, we can see that price exceeds marginal cost at a quantity of $Q_{2}$. Too little output is being produced because the value to consumers of an additional unit of output exceeds the cost to society of producing that added output. The welfare loss of monopoly is measured by this allocative inefficiency. For economists, this is the economic rationale for antitrust policy.

\subsection{Monopsony and its Welfare Consequences}

Monopsony leads to welfare effects that are analogous to those of monopoly. These effects are illustrated in Figure 2.7 Under competitive conditions, demand $(D)$ and supply $(S)$ determine a price of $w_{1}$, and a quantity of $Q_{1}$. Buyer surplus ${ }^{8}$ is equal to area $a b w_{1}$, while producer surplus equals area $w_{1} b c$. The sum, area $a b c$, is social welfare.

In contrast, suppose there is a single buyer, that is, a monopsonist. The monopsonist can take advantage of the positively sloped supply curve by restricting its purchases and thereby depressing the price that it pays. To maximize its profits, the monopsonist will purchase at the point where the marginal expenditure $(M E)$ equals demand. ${ }^{9}$ At this reduced quantity $\left(Q_{2}\right)$, the price on the supply curve is $w_{2}$. The result is a reduction in producer surplus from $w_{1} b c$ to $w_{2} e c$. Part of this reduction, area $w_{1} f e w_{2}$, is converted into buyer surplus and part of it is lost. The net effect on social welfare is a loss equal to triangular area $d b e^{10}$ Thus, the welfare results of monopsony are analogous to those of monopoly. A monopsonist reduces social welfare as well as producer welfare. The analogous value to the consumer surplus is the reduction in producer surplus created by the

\footnotetext{
7 Roger D. Blair \& Jeffrey L. Harrison, Antitrust Policy and Monopsony, 76 Connell Law Review 297, (1991)

8 We are using the term "buyer surplus" because in most monopsony settings the buyers are firms rather than consumers. The concept, however, is the same: the difference between the supplier's reservation price and the price actually received.

9 The profit function for a firm with monopsony power in the market for one input, say $x$, can be written as $\pi=P Q(x)-w(x) x$ where $P$ is output price, $Q(x)$ is the production function, and $w$ and $x$ are the price and quantity of the input. The first-order condition for profit maximization of interest is

$$
\frac{\partial \pi}{\partial x}=P \frac{\partial Q}{\partial x}-w-x \frac{d w}{d x}=0 .
$$

The value of the marginal product, $P \frac{\partial Q}{\partial x}$, is the demand for $x$ while $w+x \frac{d w}{d x}$ is the marginal expenditure. Since $\frac{d w}{d x}$ is positive, $M E>w$.

10 Although it may be somewhat counterintuitive, the lower price paid by the monopsonist does not result in lower output prices. Roger D. Blair \& Christine Piette Durrance (2008), The Economics of Monopsony in W. Dale Collins, ed., Issues in Competition LaW and Policy, Chicago: American Bar Association.
} 


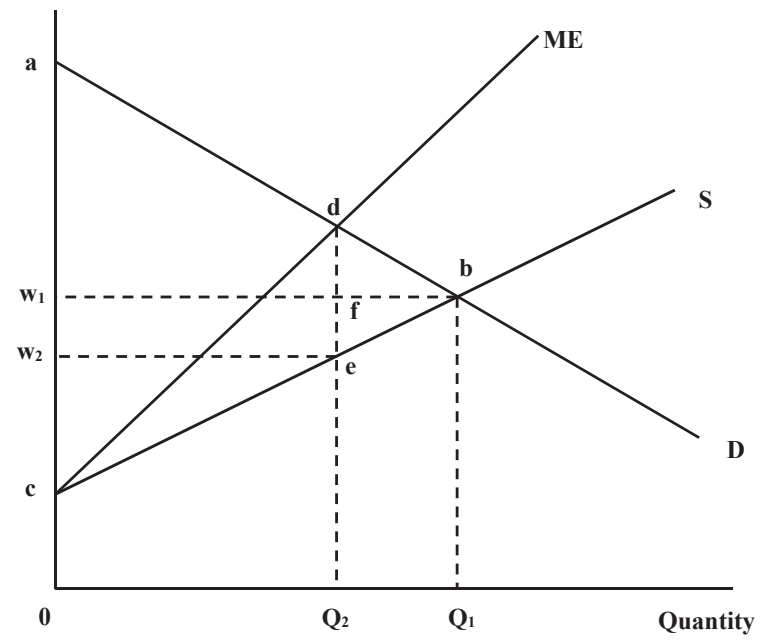

Figure 2

buyer's monopsony power. ${ }^{11}$

\section{Collusion in the Labor Market: Antitrust Policy}

The cornerstone of U.S. antitrust policy is the Sherman Act, which forbids unreasonable unilateral conduct aimed at achieving or maintaining monopoly. It also forbids conspiracies among ostensible competitors that deny market participants the benefits of competition. Although it cannot be read too literally, $\$ 1$ holds that "Every contract, combination in the form of trust or otherwise, or conspiracy, in restraint of trade or commerce among the several States ... is declared to be illegal."12

This prohibition was meant to preclude agreements not to compete on price, quantity, and quality as well as other terms on which firms would otherwise compete for business. ${ }^{13}$

For the most part, $\S 1$ is enforced by the Antitrust Division of the Department of Justice. Those found guilty of a $\S 1$ violation face stiff penalties. Corporations

\footnotetext{
11 Supreme Court rulings, such as Mandeville Island Farms, clearly illustrate that the Court has long understood this parallel. In Mandeville Island Farms, sugar beet farmers complained that the refiners colluded in an effort to depress the prices that they paid for the sugar beets. The Court recognized that the sellers were the victims of the collusive monopsony. Mandeville Island Farms v. American Crystal Sugar Co., 334 U.S. 219 (1948).

$12 \quad 15$ U.S.C. $\$ 1$

13 For a brief survey, see Roger D. Blair \& David L. Kaserman, Antitrust Economics, 2nd ed. (2009). Also, see American Bar Association, Antitrust Law Developments, 8th ed. (2016).
} 
may be fined up to $\$ 100$ million per offense. ${ }^{14}$ Individuals may be fined up to $\$ 1$ million and may be sentenced to a prison term of up to 10 years. ${ }^{15}$ These are maximum sanctions, which are rarely imposed, but the potential is there.

In addition to public enforcement, $\S 4$ of the Clayton $\mathrm{Act}^{16}$ provides a private right of action to the victims of antitrust violations: "Any person who shall be injured in his business or property by reason of anything forbidden in the antitrust laws may sue, therefor ... and shall recover threefold the damages by him sustained."'17

From the earliest days of Sherman Act enforcement, price fixing among sellers in its various forms has been unlawful. In its Mandeville Island Farms v. American Crystal Sugar Co. decision, the Supreme Court made it abundantly clear that collusion among buyers was equally impermissible. ${ }^{18}$

In Mandeville Island Farms, sugar beet farmers complained that the refiners in northern California had stopped competing on the prices paid for sugar beets. Instead, they offered uniform contracts to the farmers that resulted in identical prices. The plaintiffs contended that they received lower prices than they would have received in the absence of the allegedly unlawful agreement. Accordingly, they contended that they were entitled to recover treble damages under $\S 4$ of the Clayton Act.

The Court agreed with the plaintiffs:

It is clear that the agreement is the sort of combination condemned by the [Sherman] Act, even though the price fixing was by purchasers and the persons ... injured under the treble damage claim are sellers not customers or consumers, ... it does not follow that it is outside the scope of the Sherman Act. ${ }^{19}$

With this ruling, collusive monopsony became vulnerable to antitrust challenges by the antitrust agencies and by victims (i.e., the underpaid sellers). This antitrust policy extends to employees supplying their labor services.

There are many contemporary examples of employer cartels that have drawn antitrust fire and spawned private damage actions in the U.S. When Adobe Systems, Apple, Google, Intel, and others agreed among themselves to refrain from soliciting one another's high-tech hardware and software engineers, the Department of Justice filed suit. ${ }^{20} \mathrm{In}$ the wake of this government suit, a private damage action was filed. ${ }^{21}$ Similar suits have been filed against a host of companies that employ high-tech software and hardware engineers and digital animators. In

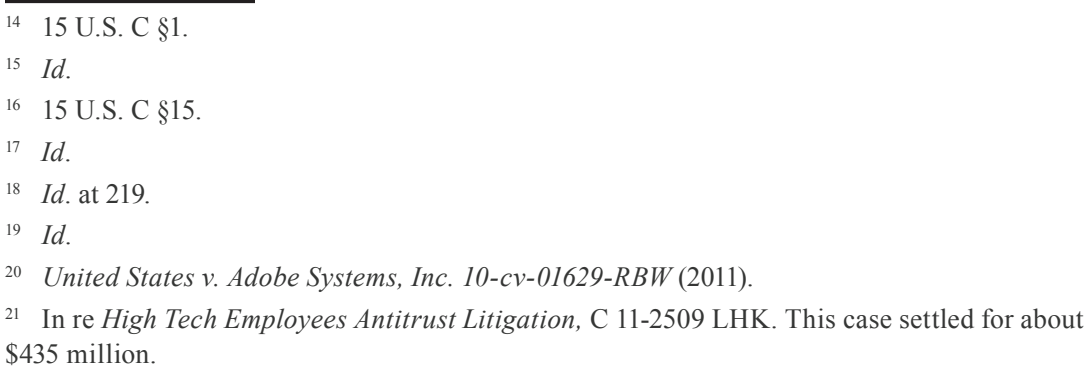


United States v. Lucas Film, ${ }^{22}$ the DOJ challenged an agreement not to poach software engineers and digital animators. A private damage action was filed against Microsoft, Dreamworks, Walt Disney, and Pixar. The Duke University and University of North Carolina hospitals allegedly engaged in a "no poaching" agreement regarding their medical staff. ${ }^{23}$ In addition to the no-poaching agreements, there have been wage fixing cases. Numerous challenges have been filed in local markets for hospital nurses. ${ }^{24}$ Employer collusion has been found in the market for fashion models and au pairs as well.

\subsection{DOJ and FTC Warnings}

In the wake of recent episodes of collusion in the labor market, the Department of Justice and the Federal Trade Commission offered advice to the community of human resources professionals in its 2016 Antitrust Guidance for Human Resources Professionals. ${ }^{25}$ The advice makes it clear that the antitrust agencies believe that collusion among employers in the labor market is a criminal offense under $\S 1$ of the Sherman Act.

The DOJ and FTC began by observing that "[f]ree and open markets are the foundation of a vibrant economy." They went on to observe that this applies to labor markets as well as product markets: “... competition among employers helps actual and potential employees through higher wages, better benefits, or other terms of employment." The DOJ and FTC made it clear that employees are entitled to antitrust protection. They take the position that "[i]t is unlawful for competitors to expressly or implicitly agree not to compete with one another even though they are motivated by a desire to reduce costs."26

The DOJ and FTC isolated two specific concerns. First, naked wage fixing agreements among competing employers are per se illegal violations of $\S 1$ of the Sherman Act. This applies to specific wages and to common wage scales. Second, agreements not to solicit or hire the employees of a competitor are also unlawful. These no-poaching agreements have been challenged by the DOJ in civil cases. The DOJ plans to open criminal investigations of suspected wage fixing and no-poaching agreements. ${ }^{27}$

\footnotetext{
22 United States v. Lucasfilm, Ltd. 10-cv-02220-RBW (2010).

23 Seaman v. Duke University, $15-c v-00462$ (2016). At this writing, the plaintiffs have settled with the University of North Carolina, but the suit against Duke University continues as a class-action.

24 See for example, Cason-Merendo v. VHS of Michigan, Inc. NO. 06-15601 (2015).

25 Available at https://www.ftc.gov/public-statements/2016/10/antitrust-guidance-human-resource-professionals-department-justice.

26 The monopsonistic suppression of wages reduces average costs and thereby improves profits, but it raises marginal costs and thereby leads to lower quantity and higher prices for consumers. Roger D. Blair \& Christine Piette Durrance, The Economics of Monopsony in W. Dale Collins, ed., Issues in Competition Law and Policy (2008).

27 In April 2018, the DOJ settled a no-poaching case, Unites States v. Knorr-Bremse 1:18-cv00747-CKK. The agency pursued this as a civil matter because it ended before the 2016 Antitrust Guidance was published. DOJ confirmed, however, that it is prepared to file criminal cases for agreements that began or continued after the Antitrust Guidance was published.
} 
The bottom line is that collusion on the buying side is impermissible under $\S 1$ of the Sherman Act. In addition, the federal anti-trust agencies have clearly stated their intentions to proceed with criminal prosecution when employers collude in the labor market. This general attitude does not apply in MLB's hiring decisions due to an egregious judicial error committed over 95 years ago. We turn our attention to the legal history of MLB's immunity in the next section.

\section{Legal Foundation for MLB's Exemption}

Ordinarily, agreements among ostensible competitors are subject to $\S 1$ of the Sherman Act. For the Sherman Act to apply, however, the suspect agreement must involve "trade or commerce" and that trade or commerce must be "interstate" in character. According to Justice Oliver Wendell Holmes, these requirements were not met in the case that started all of the mischief.

\subsection{Federal Baseball Club of Baltimore v. National League of Professional Baseball Clubs ${ }^{28}$}

The National League was organized in 1876 while the American League was organized in 1901. The champions of each league began meeting in the World Series in 1903. The two leagues cooperated with one another as Major League Baseball. In 1922, there were 16 teams in MLB. There were eight in the older National League and another eight in the relatively young American League. Geographically, professional baseball was a concentrated affair. If one divided the U.S. into four quadrants in 1920, one would have found MLB concentrated in the northeast quadrant (see Table 1). Both leagues mandated that the clubs use a standard player contract that included a reserve clause. This clause provided that the player was obligated to play one more year for his club. In practice, the clause turned a one-year contract into a perpetual contract as one year rolled into another for as long as the club desired. ${ }^{29}$ If a player refused to abide by the contractual restraints, the club would be entitled to an injunction that would prevent the player from playing for any other professional baseball club. ${ }^{30}$

In 1913, the Federal League formed and attempted to provide competition for the National and American Leagues. In 1915, the Federal League folded. One of its members, Federal Baseball Club of Baltimore, filed an antitrust suit in which it alleged that MLB clubs unlawfully agreed that all clubs would use the standard player contract with its reserve clause. All baseball players in both the major leagues and the minor leagues signed contracts that bound them to their respective clubs indefinitely. The D.C. Circuit observed that "every player was required to contract with his club that he would serve for one year, and would enter into a new contract 'for the succeeding season at a salary to be determined

\footnotetext{
$28 \quad I d$. at 200.

29 The requirement to play one more year for the player's current club could only be avoided by retiring.

30 Roger D. Blair, Sports Economics, 73-75, (2012).
} 
Table 1. Major League Baseball Teams in 1922

\begin{tabular}{l|l}
\hline American League & National League \\
\hline Boston Red Sox & Boston Braves \\
\hline Chicago White Sox & Brooklyn Robins \\
\hline Cleveland Indians & Chicago Cubs \\
\hline Detroit Tigers & Cincinnati Reds \\
\hline New York Yankees & New York Giants \\
\hline Philadelphia Athletics & Philadelphia Phillies \\
\hline St. Louis Browns & Pittsburgh Pirates \\
\hline Washington Senators & St. Louis Cardinals \\
\hline
\end{tabular}

by the parties to such contract. ${ }^{31}$ It further alleged that the clause prevented the Federal League clubs from acquiring enough high-quality players to compete with MLB teams. The plaintiff prevailed at trial and was awarded damages of $\$ 80,000$, which was trebled to $\$ 240,000$, plus costs. This verdict was appealed and the Court of Appeals for the D.C. Circuit reversed in favor of MLB. ${ }^{32}$ This decision was then appealed to the Supreme Court, which granted certiorari.

The judicial misadventures at the core of MLB's antitrust exemption began with Justice Oliver Wendell Holmes's opinion in Federal Baseball. ${ }^{33}$ The plaintiff was the lone remaining member of a league that intended to compete with the two major baseball leagues, the National League and the American League. The plaintiff alleged that the National and American Leagues had conspired to prevent successful competition from the entrant. The Supreme Court did not address this issue. Instead, the plaintiff's claim was disposed of on jurisdictional grounds. The Court found that "The business [of MLB] is giving exhibitions of baseball games, which is purely a state affair." ${ }^{34}$

In effect, since the performance of a baseball game necessarily takes place in one spot, the game itself lacks the required interstate character for the application of the Sherman Act. Justice Holmes recognized that most of the teams were located in different states and, therefore, the Brooklyn Robins had to cross state lines to play games in Chicago, Pittsburgh, and St. Louis. But he found that the transportation of teams across state lines did not carry the day for a plaintiff because the transportation was "incidental." 35 That is, the movement of one team to another state was incidental to the local performance of the baseball game.

\footnotetext{
31 National League of Professional Baseball Clubs v. Federal Baseball Club of Baltimore, Inc, 269 F. 681 (D.C. Cir, 1921).

32 Federal Baseball, 269 F. at 681.

33 Id. at 200.

34 Id. at 200.

35 Id. at 200.
} 
Importantly, Holmes did not find the business of baseball to be "trade or commerce." 36 Holmes embraced the defendants' contention that "personal effort not related to production is not a subject of commerce." 37 Presumably, those who built the ballparks, sewed the uniforms, and manufactured the baseballs were engaged in commerce while those who supplied baseball entertainment, which created the demand for ballparks, uniforms, and baseballs, were not. This finding by the Supreme Court has led many lower courts to conclude that anything that was considered to fall within the business of baseball was exempt from the Sherman Act's jurisdiction.

In our view, the opinion by Justice Holmes has two main problems, the mischaracterization of baseball being an intrastate affair and the misunderstanding of baseball not being a subject of commerce. In Toolson v. New York Yankees and Flood v. Kuhn, which will be discussed in the following sections, the Supreme Court corrected these mistakes. Nonetheless, the Court did not withdraw the exemption.

\subsection{Toolson v. New York Yankees ${ }^{38}$}

George Earl Toolson was a minor league player who was traded to another club. He refused to be traded and was then declared to be ineligible to play for any professional baseball team. Toolson filed an antitrust suit alleging that he was a victim of a concerted refusal to deal, in violation of the Sherman Act. In essence, Toolson complained about the standard player contract, which contained the reserve clause and an assortment of other restraints. The trial court accepted Federal Baseball's finding that baseball was not engaged in trade or commerce and, therefore, the Sherman Act's proscriptions did not apply. The Supreme Court agreed.

In a per curium opinion, the Supreme Court majority found that it was appropriate to maintain the notion that "the business of providing public baseball games for profit between clubs of professional baseball players [is] not within the scope of the federal antitrust laws." ${ }^{39}$ It is apparent that the majority's view was disingenuous regarding jurisdictional issues. In his dissent in Toolson, Justice Burton shattered this illusion:

In the light of organized baseball's well-known and widely distributed capital investments used in conducting competitions between teams constantly traveling between states, its receipts and expenditures of large sums transmitted between states, its numerous purchases of materials in interstate commerce, the attendance at its local exhibitions of large audiences often traveling across state lines, its radio and television activities which expand its audiences beyond state lines, its sponsorship

\footnotetext{
${ }^{36} I d$. at 200 .

37 Id. at 200 .

$38 I d$. at 346.

39 Id. at 346
} 
of interstate advertising, and its highly organized 'farm system' of minor league baseball clubs, coupled with restrictive contracts and understandings between individuals and among clubs or leagues playing for profit throughout the United States, and even in Canada, Mexico and Cuba, it is a contradiction in terms to say that the defendants in the cases before us are not now engaged in interstate trade or commerce as those terms are used in the Constitution of the United States and in the Sherman Act. ${ }^{40}$

Unwilling to revisit its earlier decision in Federal Baseball, the Court pointed to Congressional inaction: "Congress has had the ruling under consideration, but has not seen fit to bring such business under these laws by legislation having prospective effect." ${ }^{\prime 41}$ In other words, because Congress did not overrule Federal Baseball by legislative means, the Court saw no reason to correct its earlier misadventure.

The Court's majority also expressed concern that professional baseball businesses had relied on the antitrust exemption for some 30 years. ${ }^{42}$ Consequently, the Supreme Court concluded that "... if it wanted the antitrust laws to apply to professional baseball ... if there are evils in this field which now warrant application to it of the antitrust laws it should be by legislation. ${ }^{.43}$

\subsection{Flood v. Kuhn ${ }^{44}$}

After another two decades, the Court granted certiorari to confirm once again its commitment to its acknowledged error in Federal Baseball. Curt Flood was a first-rate center fielder for the St. Louis Cardinals. In addition to being one of the all-time best defensive players, he was a solid hitter. With no warning and with no apparent concern for Flood or his family, the Cardinals traded him to the Philadelphia Phillies. Under the standard player contract, he had no choice and no say in the matter. He appealed to MLB Commissioner Bowie Kuhn to be declared a free agent and thereby eligible to negotiate with any and all MLB clubs. Kuhn refused to entertain an exception to the contract for Flood.

When Flood reached the Supreme Court, the majority acknowledged that (1) MLB is a business engaged in trade or commerce and (2) that business is interstate in character. Thus, the twin pillars supporting Federal Baseball were gone. The Court also recognized that its decisions involving boxing, ${ }^{45}$

\footnotetext{
$40 \quad$ Id. at 346

41 Id. at 346.

42 Had the Supreme Court overruled Federal Baseball, the MLB clubs arguably would have been vulnerable to private damage actions for their past conduct. But there should be a way for the Supreme Court to overrule Federal Baseball while limiting private damage actions to future conduct.

43 Id. at 346 .

44 Id. at 258 .

45 United States v. International Boxing Club, 348 U.S. 236 (1955).
} 
professional football, ${ }^{46}$ and basketball ${ }^{17}$ were clearly inconsistent with Federal Baseball. Nonetheless, the Court clung to MLB's exemption. At bottom, there was no sound economic rationale or legal principle for the continuing exemption. In the end, however, the Court ruled that Congress had to act if the exemption were to be removed. ${ }^{48}$

At this point, the Supreme Court had confronted the reserve clause in Federal Baseball, Toolson, and Flood. In each case, the antitrust issue was whether the employers of professional baseball players could lawfully agree to impose the same restraint on their employees. If the decision to include the reserve clause in the contracts had been unilateral, there could have been no $\S 1$ violation. But an agreement among employers to include the identical clause in all employment contracts would seem to satisfy the "contract combination ... or conspiracy" requirement for a $\S 1$ violation. If that agreement were judged to be unreasonable in an antitrust sense, then it would violate $\$ 1$. The Court dodged this issue in Federal Baseball on jurisdictional grounds. This reasoning has been disavowed in Justice Burton's dissent in Toolson and by the majority in Flood.

John Paul Stevens, a former Supreme Court Justice, has pointed out that the Supreme Court precedents apply only to the reserve clause. ${ }^{49}$ They do not apply to MLB's dealings with umpires, scouts, broadcasters, and others doing business with MLB and its clubs. Nonetheless, some lower courts appear to think so. ${ }^{50}$

\subsection{Curt Flood Act of $1998^{51}$}

In Flood v. Kuhn, the Supreme Court relied on stare decisis to rationalize its perpetuation of MLB's antitrust exemption. Some 50 years after Federal Baseball, the Court unequivocally shifted the burden of removing MLB's antitrust immunity to Congress. Although Congress did not exactly leap into action, it did pass the Curt Flood Act, a quarter of a century after the Supreme Court's decision in the Flood Case. This apparently bold step is largely irrelevant.

The sole purpose of the Act is to make the antitrust laws applicable to MLB in its dealings with MLB players. This, of course, appears to be an enormous change, but its significance is nearly nonexistent. The players have been unionized since 1965. Consequently, the terms of employment are governed by the collective bargaining agreement, which should protect the players from monopsonistic exploitation by the clubs. Such agreements are shielded from most antitrust challenges by the nonstatutory labor exemption. ${ }^{52}$ At the risk of sounding

\footnotetext{
46 Radovich v. National Football League, 352 U.S. 445 (1957).

47 Haywood v. National Basketball Assn., 401 U.S. 1204 (1971).

$48 I d$. at 258.

49 John Paul Stevens. Sports Lawyers Association 41st Annual Conference Luncheon. (2015).

50 The reserve clause was killed in arbitration when Dave McNally and Andy Messersmith challenged the "ever green" interpretation of the standard contract.

51 The Curt Flood Act of 1998 amended the Clayton Act by adding a new section: 15 U.S.C. $\$ 27$.

52 For a brief statement of the nonstatutory labor exemption, see ABA Section of Antitrust Law, Antitrust Law Developments, 8th ed. 1495-1499 (2017).
} 
cynical, we should observe that Congress failed to provide antitrust protection for the players until they no longer needed it.

Importantly, all other aspects of the business of baseball may still be exempt from the antitrust laws. The Act does not protect minor league players. Since minor league players are not unionized, they may be exposed to the monopsonistic agreements of the MLB owners.

In addition to minor league baseball, the Act specifically enumerates agreements on the amateur draft, franchise expansion, location or relocation, franchise ownership issues including ownership transfers, the relationship between the Office of the Commissioner and franchise owners, the marketing or sales of the entertainment product of organized professional baseball, and the licensing of intellectual property as being beyond the scope of the Curt Flood Act. In addition, the Act similarly fails to protect agreements relating to umpires and others employed in the business of organized professional baseball. ${ }^{53}$

\section{Current Vitality of MLB's Antitrust Immunity}

In spite of repeated setbacks in court, the anticompetitive conduct of MLB has resulted in federal antitrust suits. We begin with a brief discussion of City of San Jose v. Office of Commissioner of Major League Baseball, ${ }^{54}$ which deals with restraints on the relocation of MLB franchises. We then turn our attention to two cases that involve monopsonistic abuse: Miranda v. Selig, ${ }^{55}$ which involved a wage-fixing agreement for minor league ballplayers, and Wyckoff v. Office of Commissioner of Baseball, ${ }^{56}$ which involved a no-poaching agreement for baseball scouts. Both challenges failed due to the continuing vitality of the Federal Baseball exemption. Finally, we examine Garber v. Office of Commissioner of Baseball, ${ }^{57}$ a market allocation case that appeared to be heading south for MLB before the parties settled.

\subsection{Restraints on Relocation: City of San Jose v. Office of Commissioner of Major League Baseball}

In City of San Jose, the plaintiff alleged that MLB's restraints on the relocation of MLB clubs violated $\S 1$ of the Sherman Act. It is undisputed that each MLB club operates within its exclusive territory. The Oakland Athletics wanted to relocate to San Jose for financial reasons. Unfortunately, San Jose falls within the exclusive territory of the San Francisco Giants. As a result, the Oakland Athletics could not move to San Jose without the approval of at least $75 \%$ of the MLB franchises.

\footnotetext{
53 There have been some lower court decisions involving parties and practices that are not covered by the Curt Flood Act, but there has been no Supreme Court guidance on these issues.

${ }^{54}$ City of San Jose v. Office of the Commissioner of Baseball, 776 F.3d 686 (9th Cir. 2015).

${ }_{55}$ Miranda v. Selig, 860 F.3d 1237 (9th Cir. 2017).

56 Wyckoff v. Office of the Commissioner of Baseball, 2016 U.S. Dist LEXIS 135443 (S.D.N.Y. 2016)

57 Garber v. Office of the Commissioner of Baseball, 120 F. Supp. 3d 334, Dist. Court, SD New York (2017).
} 
The Athletics and the city of San Jose had struck a deal on a site for a new ballpark pending approval of the relocation by MLB. In 2009, MLB formed a committee to study the effects of the proposed relocation, but four years later, the committee was still analyzing the impact of such a potential move. Suspicious that this was just a stalling tactic aimed at preserving the Giants' local monopoly, the City of San Jose filed an antitrust suit. In response, MLB filed a motion to dismiss on the grounds that MLB was exempt from the antitrust laws. The district court granted MLB's motion to dismiss. ${ }^{58}$ The City of San Jose appealed.

The Ninth Circuit reviewed the Supreme Court's holdings in the Federal Baseball-Toolson-Flood trilogy and found that the present antitrust immunity rested on two considerations. ${ }^{59}$ First, the "principle of Stare Decisis and the concomitant aversion to disturbing reliance interests" $" 60$ created by the exemption made the Supreme Court reluctant to overturn Federal Baseball. Second, Congress was well aware of Federal Baseball and acquiesced to its holding. The City of San Jose argued, however, that the exemption applied only to the reserve clause, which was at issue in the MLB trilogy ${ }^{61}$ Therefore, the City of San Jose alleged that the exemption did not apply to restraints on relocation of clubs.

The Ninth Circuit disagreed. In the Supreme Court precedents, the Ninth Circuit found support for the proposition that the antitrust exemption applied "to the entire business of providing public baseball games for profit between clubs of professional baseball players." $" 62$

The Ninth Circuit further found that "[t]he Supreme Court intended to exempt the business of baseball, not any particular facet of that business, from the federal antitrust laws." ${ }^{63}$ The court was persuaded that limits on franchise location and relocation fall squarely within the business of baseball.

"The designation of franchises to particular geographic territories is the league's basic organizing principle ... few, if any, issues are as central to a sports league's proper functioning as its rules regarding the geographic designation of franchises." ${ }^{64}$ In the Ninth Circuit's view, therefore, the City of San Jose's

\footnotetext{
58 City of San Jose, 776 F.3d at 686.

$59 \quad I d$. at 686.

60 Id. at 686.

${ }^{61}$ As noted above, supra note 48 and accompanying text, former Supreme Court Justice John

Paul Stevens agreed with this position.

62 Toolson, 346 U.S. at 357.

$63 \quad I d$. at 686.

64 Id. at 686.
} 
antitrust claims were properly dismissed by the district court. Thus, for decades after Flood, MLB's exemption appeared to be as safe as ever. ${ }^{65}$

The court could have interpreted the business of baseball to be the production of baseball games for public consumption. In that event, one could reasonably argue that the creation of local monopolies and their protection with relocation restraints are outside the business of baseball. Although creating and protecting local monopolies would enhance profits, it would not improve the business of baseball. The court, however, did not adopt this reasoning.

\subsection{Wage Fixing: Miranda v. Selig ${ }^{66}$}

A number of minor league baseball players filed a class-action antitrust suit against MLB in 2017. In their complaint, they alleged that the members of MLB violated $\S 1$ of the Sherman Act in their dealings with minor league baseball players.

The Court of Appeals recognized that minor league baseball players were required to sign a uniform player contract that contained a reserve clause. The court observed that

Under the contract's so-called 'reserve clause,' MLB franchises receive exclusive rights to their minor league players for seven championship seasons, approximately seven years. This provision precludes players from playing for any other baseball team during the contract period, whether or not the team is an MLB franchise. However, MLB franchises have the power to transfer amongst themselves their exclusive rights to a player at the end of each contract season. ${ }^{67}$

With no union to protect them, minor league players are paid little. During spring training, they may work 50-60 hours per week with no pay at all. During the season, their pay depends on the level of their play. According to the Ninth Circuit, the alleged salary scale imposed by MLB on the minor league players is shown in Table 2. According to the plaintiffs, most minor league players earned less than $\$ 7,500$ per year and some earned as little as $\$ 3,000$ a year. ${ }^{68}$

${ }_{65}$ Similarly, in Right Field Rooftops, the plaintiffs' suit was dismissed. In their suit, the plaintiffs requested a preliminary injunction to prevent the Chicago Cubs from constructing a Jumbotron and billboards that would block the view of live games by customers of businesses across the street from Wrigley Field. Part of their complaint alleged that the Cubs were attempting to monopolize attendance at live Cubs games in violation of $\S 2$ of the Sherman Act. The district court denied the request on several grounds. Significantly, the court found that the business of baseball enjoyed an antitrust exemption that precluded success on the merits and, therefore, an injunction would be inappropriate. Right Field Rooftops, L.L.C. v. Chicago Baseball Holdings, L.L.C., 87 F. Supp 3d 874 (N.D. I11. 2015). The Supreme Court denied certiorari. Right Field Rooftops, L.L.C. v. Chicago Baseball Holdings, L.L.C., 138 S.Ct. 2621, U.S., June 11, 2018.

${ }_{66}$ Miranda v. Selig, 860 F.3d 1237 (9th Cir. 2017).

${ }^{67}$ Id. at 1239 .

68 In contrast, the minimum salary for an MLB player was $\$ 535,000$ per season in 2017. Collective Bargaining Agreement, Article 6, Section A, Paragraph 1, available at http://www.mlbplayers. com/pdf9/5450407.pdf 
Table 2. Salary Scale for Minor League Baseball Players

\begin{tabular}{c|c}
\hline Class & Monthly Salary \\
\hline First Year & $\$ 1,100$ \\
\hline Class A & $\$ 1,250$ \\
\hline Class AA & $\$ 1,500$ \\
\hline Class AAA & $\$ 2,150$
\end{tabular}

Note: These data were extracted from Miranda v. Selig, 860 F.3d 1237 (9th Cir. 2017).

The players filed an antitrust suit alleging that the MLB clubs violated $\S 1$ of the Sherman Act by colluding on the uniform player contract and the minor league salary structure ${ }^{69}$ In response to the complaint, MLB filed a motion to dismiss the complaint on the ground that the business of baseball is exempt from the antitrust laws. The district court agreed and dismissed the suit. The plaintiffs appealed this ruling to the Ninth Circuit, which affirmed the lower court's decision. In doing so, the court explained that it was bound by both Supreme Court and Ninth Circuit precedent, which conferred and confirmed baseball's antitrust exemption. ${ }^{70}$

In its opinion, the Ninth Circuit relied on the Supreme Court's rulings in Federal Baseball, Toolson, and Flood as well as the language in the Curt Flood Act, which specifically exempted minor league baseball from the provisions of the Act.

Sergio Miranda and a number of other minor league players filed a petition for a Writ of Certiorari seeking Supreme Court review. In the petition, they raised three questions. First, they asked whether Federal Baseball should be reversed. Second, they asked whether a collusive agreement to fix the salaries of minor league baseball players violates $\S 1$ of the Sherman Act. Finally, they asked whether the Curt Flood Act is unconstitutional as it denies equal protection to minor league baseball players from antitrust violations.

Clearly, Miranda provided an opportunity for the Supreme Court to correct an error committed nearly 100 years ago. The Court greeted this opportunity with a resounding "cert. denied." 71

If the business of baseball is the production and performance of MLB games, one could reasonably argue that minor league operations fall outside the business of baseball. This interpretation would have made MLB's wage-fixing agreement vulnerable to antitrust challenge. Having adopted a more expansive definition, the court could have banned MLB's monopsonistic abuses of minor league players, but it failed to do so.

\footnotetext{
${ }^{69}$ In other employment settings, an agreement among employers on a wage scale would be a criminal violation of the Sherman Act according to the DOJ and FTC's Antitrust Guidance for Human Resources Professionals.

70 Miranda v. Selig, 860 F.3d 1237 (9th Cir. 2017).

$71 \quad 138$ S.Ct. 507 (2017).
} 


\subsection{No-Poaching Agreements: Wyckoff v. Office of the Commissioner of Baseball ${ }^{72}$}

At issue in this case were the formal (i.e., contractual) and informal restraints in the market for baseball scouts employed by MLB clubs. The 30 MLB clubs employ over 1,000 scouts. These scouts travel all over the U.S. and to some foreign countries to evaluate baseball talent. They attend high school, college, and professional games in an effort to find players with Major League potential. The scouts report their evaluations to the club that employs them and the clubs rely on those scouting reports to select players to hire. In this regard, scouting services are valuable to the clubs.

Baseball scouts are hired by the MLB clubs, which use a uniform employee contract. All MLB clubs use this uniform contract, which is prescribed by the commissioner. Ordinarily, these are one-year contracts and contain an exclusivity provision. During the term of the contract, a scout may not provide scouting services to any other club. The uniform contract also has an anti-tampering provision. When a scout is under contract, he or she may not negotiate future employment with any other club unless he or she has been given permission to do so.

Jordan Wyckoff and a number of other baseball scouts alleged that the clubs agreed among themselves on a salary structure that depressed compensation below competitive levels. ${ }^{73}$ In addition, they alleged that the anti-tampering or no-poaching provisions in the uniform contract made it very difficult for a scout to find another job if his or her current club did not renew the contract. ${ }^{74}$

The defendants filed a motion to dismiss on the grounds that Wyckoff failed to state a claim upon which the court could grant relief. ${ }^{75}$ The district court granted the motion to dismiss since it decided that Wyckoff could not meet his burden of proof under Supreme Court precedent, Ninth Circuit precedent, and the Curt Flood Act. ${ }^{76}$

No-poaching agreements are not necessary for the success of MLB. They reduce competition, and, therefore, make the clubs more profitable. They are not ancillary agreements that promote the larger venture (i.e., MLB itself). In other words, no-poaching agreements do not contribute to the production of MLB games for public consumption.

\footnotetext{
72 Wyckoff v. Office of the Commissioner of Baseball, 2016 U.S. Dist LEXIS 135443 (S.D.N.Y. 2016)

73 Wyckoff's salary was only $\$ 15,000$ per year. Moreover, he was paid no overtime even though he often worked more than 40 hours in a week. Id. at 620 .

74 All of the major sports leagues have restrictions on poaching or tampering with personnel under contract. For an evaluation of this restraint see Roger D. Blair. \& John E. Lopatka, The Economic Effects of Anti-Tampering Rules in Professional Sports Leagues, 38 MANAGERIAL AND Decision Economics 704, (2017).

75 At this initial pleading stage, a plaintiff must allege sufficient facts, which if true, state a claim for relief that is plausible on its face. Failure to satisfy this pleading requirement is grounds for dismissal. Bell Atlantic Corp v. Twombly, 127 S.Ct. 1955 (2007).

${ }^{76}$ Cert was denied for this case. Wyckoff v. Office of the Commissioner of Baseball, $138 \mathrm{~S}$.Ct. 2621, (2018).
} 


\subsection{Broadcasting Restraints: Garber v. Office of the Commissioner of Baseball ${ }^{77}$}

Not all recent decisions have gone MLB's way. In Garber, the district court agreed that monopolistic restraints in broadcasting MLB games fell outside the scope of MLB's antitrust exemption.

In order to maximize the value of broadcast licenses, MLB carved up the country into exclusive home territories for each club. ${ }^{78}$ Each club was then able to license its TV broadcast rights to a regional sports network (RSN). The RSN then sold the programming to cable and satellite companies for resale to their subscribers. In doing so, MLB created a series of local monopolies. As a result, a Royals fan who lives in the Royals' home territory could not view the Royals' away games because of exclusivity provisions in the license agreements. Similarly, a Yankees fan who lives in the Royals' home territory could not view the Yankees' home games. Thus, a Yankees fan could only watch the Yankees play when they play against the Royals. Again, this was due to exclusivity provisions that protect the local monopoly, but it left some unmet demand. MLB stepped in with two additional services that filled these unmet demands. A fan, who wanted access to out-of-market games, could subscribe to MLB Extra Innings for cable access or to MLB.TV for Internet streaming. By imposing a variety of restraints, MLB and its members were able to restrict choices and charge monopoly prices.

Fernanda Garber and other MLB fans filed a class-action antitrust suit alleging that MLB's exclusive agreements and restrictions violated the Sherman Act. In response, MLB filed a motion for summary judgement and cited its antitrust exemption. The district court denied the motion and held that the geographic division of broadcast territories did not fall within the business of baseball that is covered by the exemption.

The case settled before going to trial. The settlement provided expanded choices to fans and reduced prices. ${ }^{79}$

It is somewhat unfortunate that the case settled before the district court's ruling on the applicability of MLB's antitrust exemption could be reviewed. The settlement vacates all of the rulings and, therefore, Garber has no precedential value. The ruling in Garber does suggest, however, that some judges are willing to confine the antitrust exemption to some extent.

\footnotetext{
77 Garber v. Office of the Commissioner of Baseball, 120 F. Supp. 3d 334, Dist. Court, SD New York (2017).

78 The exceptions then included Chicago, New York, and San Francisco.

79 For a brief discussion of the terms of the settlement, see Sports Illustrated article, Major League Baseball Settles Lawsuit over Television Blackouts. Available at https://www.si.com/ mlb/2016/01/19/garber-case-settlement-tv-packages. For more detail, David Fucillo (2016) MLB. TV Lawsuit Settlement Means Cheaper Extra Innings, MLB.TV Packages. SBNation. Available at https://www.sbnation.com/mlb/2016/2/11/10966352/mlb-tv-lawsuit-settlement-details-extra-innings-mlb-tv-packages-cheaper
} 


\subsection{Summary}

The results of recent antitrust challenges suggest that MLB's antitrust exemption is secure. Plaintiffs have offered creative arguments in their efforts to distinguish Federal Baseball and its progeny, but most lower courts are following precedents that have no economic foundation. What appears to be necessary is a Supreme Court that will reconsider Federal Baseball and correct its error, which is nearly 100 years old.

\section{Judicial Resistance to Repeal of Federal Baseball}

Justice Holmes erred badly in Federal Baseball nearly 100 years ago by granting antitrust immunity to MLB. This special treatment has not been extended to any other sports league or organization, nor should it be. ${ }^{80}$ At a time when the DOJ is threatening criminal prosecution for wage fixing and no-poaching agreements, MLB continues to be free to engage in these monopsonistic practices.

There is no legitimate rationale for MLB's antitrust exemption and it should be withdrawn. This can be accomplished judicially or legislatively.

The Supreme Court has already acknowledged that Federal Baseball was a mistake. In Flood, it justified inaction on its part by pointing to stare decisis (i.e., respect for precedent) and inaction by Congress. Neither should be a barrier to a sensible and consistent antitrust policy.

\subsection{The Stare Decisis Trap}

Judicial respect for precedent is important for the stability of our legal system. If earlier decisions have no precedential value, then no one will know what conduct is permissible and what is not. The resulting uncertainty impedes transactions and investments that are Kalder-Hicks efficient ${ }^{81}$ to the detriment of social welfare. At the same time, stare decisis can trap society in a sub-optimal state if a judicial precedent is "wrong," that is, inefficient in an economic sense.

In the case of Federal Baseball, even the Supreme Court acknowledges that it was wrongly decided. In Flood, for example, the Court recognized that

1. "Professional baseball is a business and it is engaged in interstate commerce."

2. "With its reserve system enjoying immunity from the federal antitrust laws, baseball is, in a very distinct sense, an exception

${ }^{80}$ Radovich v. National Football League, 352 U.S. 445 (1957) and Haywood v. National Basketball Assn., 401 U.S. 1204 (1971).

${ }^{81}$ Economists have long recognized that interpersonal welfare comparisons are impossible, so it is unwise to compare a gain to one person with a loss to another. If, however, the beneficiaries of a change could compensate the losers and still come out ahead, that change is said to be KalderHicks efficient. See Nicholas Kalder, Welfare Propositions of Economics and Interpersonal Comparisons of Utility, 49 Economic Journal 549 (1939), and J.R. Hicks: Foundations of Welfare Economics, 49 ECONOMIC Journal 696 (1939). 
and an anomaly. Federal Baseball and Toolson have become an aberration confined to baseball." ${ }^{82}$

Unfortunately, the Supreme Court concluded that "[e]ven though others might regard this as 'unrealistic, inconsistent, or illogical,' ... the aberration is an established one..." Consequently, the Supreme Court did nothing to correct the error that it committed in Federal Baseball.

In spite of its general respect for precedent, the Supreme Court does correct its past blunders from time to time. Its decision in Continental T.V. ${ }^{84}$ overruled its Schwinn ${ }^{85}$ precedent. It overruled Albrecht ${ }^{86}$ in State Oil ${ }^{87}$ and overruled Dr. Miles $^{88}$ in Leegin. ${ }^{89}$ Thus, the Court's adherence to its precedents is far from absolute.

In those instances, the Court initially erred in finding a business practice to be invariably anticompetitive where subsequent economic analysis found that not to be so. In the case of MLB's exemption, the Court would be subjecting MLB to the same antitrust rules as all other sports leagues.

Since the Flood decision in 1972, there have been many antitrust challenges to the anticompetitive conduct by MLB. All of them have been stymied by the Federal Baseball precedent. The courts will continue to have opportunities to correct the error of Federal Baseball. This is the way that the law evolves.

The evolutionary models of legal change suggest that precedents that are Kaldor-Hicks inefficient will be challenged because the gains to the winners will exceed the losses to the losers. ${ }^{90}$ MLB's antitrust exemption is clearly inefficient on Kaldor-Hicks grounds since it permits both monopolistic and monopsonistic exploitation, which are necessarily inefficient. In Flood, the Court unambiguously said that it would not overrule Federal Baseball, but would leave it to Congress to correct the Court's errs regarding MLB's exemption. Since Flood is 47 years old, the Court's determination to do nothing may have waned. Consequently, it is important for aggrieved parties to continue filing suits. In the absence of antitrust challenges, there would be no opportunity for the Supreme Court to change course and overrule Federal Baseball.

There are costs and benefits of correcting an inefficient legal rule. Since the benefits necessarily outweigh the costs, continued legal challenges result.

82 Flood, 407 U.S. at 2105.

83 Id. at 2107.

84 Continental T.V., Inc v. GTE Sylvania, Inc., 433 U.S. 36 (1977).

85 United States v. Arnold, Schwinn \& Co., 388 U.S. 365 (1967).

86 Albrecht v. Herald Co., 390 U.S. 145 (1968).

87 State Oil Co. v. Kahn, 118 U.S. 275 (1997).

88 Dr. Miles Medical Co. v. John D. Park \& Sons Co., 220 U.S. 373 (1911).

89 Leegin Creative Leather Products, Inc., v. PSKS, Inc. 127 U.S. 2705 (2007).

90 Richard A. Posner, Economic Analysis of Law (1973), observed that the common law evolved toward efficient legal rules. Paul Rubin, Why Is the Common Law Efficient? 6 Journal of Legal Studies 51 (1977), and George Priest \& Benjamin Klein, The Selection of Disputes for Litigation, 13 Journal of Legal Studies 1 (1984) formalized Posner's observation. 


\subsection{Congressional Inaction}

There is ample evidence that Congress was well aware of MLB's antitrust exemption. With the exception of the Curt Flood Act, Congress has been a pillar of inaction. Given the political process, this is not too surprising. Congress is vulnerable to determined lobbying efforts. ${ }^{91}$ Those with much to gain (or lose) may well be more determined than those in opposition. The beneficiaries of the exemption are wealthy, influential club owners, while the victims, such as scouts, umpires, and minor league players, are small in number or politically unconnected. To the extent that fans are victims, they are vast in number, their injury may be substantial in the aggregate, but diffused. Put differently, each fan's injury will be small and not worth pursuing vigorously.

In Toolson and again in Flood, the Supreme Court rationalized its own inaction in failing to correct its Federal Baseball mishap by pointing to Congress's inaction in not legislatively overturning Federal Baseball. This seems a bit odd. Congress did not take any affirmative steps to exempt MLB from the reach of the Sherman Act. Although it was the Court that created the MLB exemption, the Court holds Congress responsible for undoing the exemption. We think that this responsibility is misplaced.

\section{Proposed Reform: Withdraw MLB's Antitrust Exemption}

There is no obvious reason why MLB's antitrust exemption should not be withdrawn. The original rationale for antitrust immunity was jurisdictionalMLB was not engaged in "trade or commerce" and what it was engaged in was not "interstate" in character. These fictions have long been abandoned. Consequently, the Supreme Court could revisit Federal Baseball and simply overrule it. Alternatively, Congress could expand the coverage of the Curt Flood Act to include the business of baseball. In either case, MLB and its member clubs would still have to impose a variety of restraints if they are going to produce competition on the field. Those restraints would be subject to antitrust scrutiny under the rule of reason. Those restraints that are procompetitive on balance would be permissible while those that are not would be unlawful.

It is generally understood that sports leagues must collaborate on many dimensions. These include rules of play, roster size, equipment, schedules, playoff structure, and championships. The absence of agreements on these issues would result in confusion and reduce fan satisfaction. Cooperation would seem to be procompetitive and, therefore, desirable.

There are a host of current restraints, however, that would not pass muster under the rule of reason. Agreements that restrain competition in labor markets

91 For economic analyses of these political difficulties, see George Stigler, The Theory of Economic Regulation, 2 The Bell Journal of Economics and Management Science, 3 (1971) and Sam Peltzman, Toward a More General Theory of Regulation, 19 Journal of LAW AND ECONOMICs, 211 (1976). 
would be hard to justify. ${ }^{92}$ Horizontal agreements among the MLB clubs restricting competition for major league players, minor league players, umpires, scouts, coaches, and front office personnel would be anticompetitive on their face. Consequently, without more, these agreements would violate $\S 1$ of the Sherman Act. In response, the clubs would have to provide procompetitive justifications to offset the anticompetitive effects. MLB and its members might turn to competitive balance as a rationale for collusion, but this argument should fail. First, there is no conclusive evidence that fans actually care about competitive balance. For instance, fans of a lower-ranked team may simply want to see the well-known players from the top teams even though the uncertainty of the game result is very low. ${ }^{93}$ Second, neither depressing salaries directly by exercising monopsony power nor doing so indirectly by curtailing free agency will improve competitive balance. ${ }^{94}$ Consequently, this argument should be rejected in a rule of reason analysis.

\section{Conclusion}

Nearly 100 years ago, Oliver Wendell Holmes stumbled in his Federal Baseball opinion and exempted MLB from antitrust scrutiny. In subsequent decisionsToolson and Flood - the Court recognized its earlier mistake, but refused to correct it. The time has come for the Court to review the unwarranted exemption and subject the business of baseball to the same rules that govern the conduct of the

\footnotetext{
92 In a speech at the Economic Policy Institute and Open Markets Institute conference, FTC Commissioner Rohit Chopra called for more attention to employer conduct that limits compensation and other terms of employment. Available at https://www.ftc.gov/system/files/documents/ public statements/1408196/chopra - comment to hearing 1 9-6-18.pdf

93 The empirical evidence of the impact of competitive balance on fan demand has been mixed. Earlier papers such as Glenn Knowles, Keith Sherony, \& Mike Haupert, The Demand for Major League Baseball: A Test of the Uncertainty of Outcome Hypothesis, 36 The American Economist 72 (1992), and Daniel A. Rascher, A Test of the Optimal Positive Production Network Externality in Major League Baseball, in John Fizel, Elizabeth Gustafson, \& Lawrence Hadley, eds., Sports Economics: Current Research 27 (1999), find that competitive balance increased MLB game attendance. More recent papers such as James W Meehan., Randy A. Nelson, \& Thomas V. Richardson, Competitive Balance and Game Attendance in Major League Baseball, 8 Journal OF SPORTS EConomics 563 (2007), Brian Soebbing, Competitive Balance and Attendance in Major League Baseball: An Empirical Test of the Uncertainty of Outcome Hypothesis, 3 International JournaL of Sport Finance 119, (2008). Scott Tainsky \& Jason Winfree, Short-Run Demand and Uncertainty of Outcome in Major League Baseball, 37 Review of Industrial Organization 197 (2010), find that the effect of competitive balance on attendance depends on the timing in the season, the current standings of the teams, the importance of the game in qualifying for playoffs, the team's change in performance between seasons, and the league-wide competitive balance. Furthermore, Young Hoon Lee \& Rodney D. Fort, Attendance and the Uncertainty-of-Outcome Hypothesis in Baseball, 33 Review of Industrial Organization 281 (2008), suggest that only the uncertainty during the playoffs improve game attendance. Thus, Rodney D. Fort, Pro Sports League Antitrust 'Beliefs': Applied Theory and the Rule of Reason, 38 Managerial and Decision Economics 655 (2017) argues that it is only a hypothesis that fans prefer more competitive balance, and therefore, it must be proved in every case.

94 James Quirk \& Rodney D. Fort, Pay Dirt: The Business of Professional Team Sports, (1992).
} 
other sports leagues and organizations. Neither stare decisis nor Congressional inaction provides a basis for the Supreme Court's reluctance to overturn Federal Baseball. Continuing special treatment cannot be justified and the Court should put an end to it. Oliver Wendell Holmes observed that "it is revolting to have no better reason for a rule of law than that is was so laid down in the time of Henry IV. It is still more revolting if the grounds upon which it was laid down have vanished long since and the rule simply persists from the blind imitation of the past" ${ }^{95}$ Presumably, Holmes would apply this bit of wisdom to his ruling in Federal Baseball.

95 See Holmes, The Path of the Law, 10 Harvard Law Review, 457, 469 (1897). 